\title{
Prevalence of oral hairy leukoplakia in 120 pediatric patients infected with HIV-1
}

\section{Prevalência da leucoplasia pilosa oral em 120 pacientes pediátricos infectados pelo HIV-1}

\author{
Eliane Pedra Dias* \\ Mônica Simões Israel** \\ Arley Silva Junior** \\ Vanessa Abreu Maciel*** \\ José Paulo Gagliardi**** \\ Ricardo Hugo Oliveira*****
}

\begin{abstract}
Oral hairy leukoplakia (OHL) is an EBV (Epstein-Barr virus) opportunistic infection found in HIV-infected patients. It is an asymptomatic lesion that has an important prognostic value in AIDS. Differently from what takes place with HIV adult patients, OHL has been described in the literature as having a very small prevalence in pediatric patients. Therefore, the aim of this study was to investigate the prevalence of OHL in HIV pediatric patients using cytopathology. The sample consisted of 120 patients who were submitted to oral examination and had material scraped from both sides of their tongues. The diagnostic criterion was based on the identification of nuclear alterations. Clinical OHL was identified in two $(1.67 \%)$ patients. The cytopathology revealed twenty $(16.7 \%)$ cases of subclinical OHL. Our results show that in pediatric patients the prevalence of OHL may be larger than that described in the literature.

DESCRIPTORS: Acquired immunodeficiency syndrome; Leukoplakia, hairy; Epstein-Barr virus infections; Cells/ pathology.
\end{abstract}

\begin{abstract}
RESUMO: A leucoplasia pilosa oral (OHL) é uma infecção oportunista causada pelo Vírus Epstein-Barr (EBV) encontrada em pacientes infectados pelo HIV. É uma lesão assintomática que tem um importante valor prognóstico na AIDS. Diferentemente de pacientes adultos, a OHL tem sido descrita na literatura como tendo uma prevalência muito pequena em pacientes pediátricos. Logo, o objetivo deste estudo foi investigar a prevalência da OHL em pacientes pediátricos positivos para o HIV através do uso da citopatologia. A amostra consistiu-se de 120 pacientes, que foram submetidos a exame oral e coleta de material de ambos os lados da língua. O critério diagnóstico foi baseado na identificação de alterações nucleares. A OHL clínica foi identificada em dois (1,67\%) pacientes. A citopatologia revelou vinte casos $(16,7 \%)$ de OHL subclínica. Nossos resultados mostram que a prevalência de OHL em pacientes pediátricos infectados pelo HIV deve ser maior que a relatada na literatura.

DESCRITORES: Síndrome de imunodeficiência adquirida; Leucoplasia pilosa; Infecções por vírus Epstein-Barr; Células/patologia.
\end{abstract}

\section{INTRODUCTION}

Human immunodeficiency virus (HIV) infection was first recognized in children in 1983. Although the disease's course has many similarities between children and adults, there are some differences, including risk factors, mode of transmission, patterns of seroconversion, natural history and spectrum of the disease. The oral manifestations of pediatric HIV infection are scarce, and the spectrum of the clinical lesions differs considerably from that of an adult ${ }^{17}$. Oral hairy leukoplakia (OHL) was first described in 1984 and was considered to be an early marker of HIV infection in adults. It is associated with the Epstein-Barr virus (EBV), a double-stranded DNA virus which belongs to the human herpesvirus group ${ }^{7,14}$.

Clinically, OHL manifests itself as a flat, corrugated or hairy nonremovable asymptomatic white lesion, most commonly on the lateral border and/

*Full Professor, Department of Pathology, School of Medicine; **MScs in Bucodental Pathology; ***Scientific Initiation Student, Discipline of Pathology, School of Dentistry - Fluminense Federal University.

**** Director, Virology Laboratory, Oswaldo Cruz Institute, RJ.

$* * * * *$ MD, Head of the Pediatric AIDS Service, Martagão Gesteira Institute of Child Care and Pediatrics, Federal University of Rio de Janeiro. 
Dias EP, Israel MS, Silva Junior A, Maciel VA, Gagliardi JP, Oliveira RH. Prevalence of oral hairy leukoplakia in 120 pediatric patients infected with HIV-1. Braz Oral Res 2006;20(2):103-7.

or ventral surface of the tongue ${ }^{10}$. Histopathologic features, such as ballooning degeneration of keratinocytes of the upper stratum spinosum, epithelial hyperplasia with hyperparakeratosis, and mild or absent subepithelial inflammation were considered unspecific. However ${ }^{11}$, some authors concluded that the histopathologic features of OHL were highly specific if based on nuclear changes, which were easy to identify: Cowdry type A inclusions, ground-glass nuclei, and a light nuclei with peripheral margination and clumping of chroma$\operatorname{tin}^{7,11,22}$. In 1992, Fraga-Fernande $z^{11}$ concluded that the conventional cytopathology, based on nuclear features, might prove to be a useful, simple, low cost, and reliable method to diagnose OHL. Migliorati et al. ${ }^{22}$ (1993) and Dias et al. ${ }^{6}$ (1998) reported similar results ${ }^{11,22}$.

Subclinical OHL was first described in 1995 by Mabruk et al. ${ }^{20}$ (1995). These authors reported that 2 out of 15 AIDS postmortem tongues were positive for EBV despite normal clinical appearence of the mucosa. In that study, the authors suggested that in situ hybridization is sufficiently sensitive to detect very early or subclinical EBV infection ${ }^{20}$. Dias et al. ${ }^{7}$, in 2001 investigated the presence of nuclear features indicative of EBV infection in clinically normal lateral borders of tongue smears of 50 patients with AIDS. Nuclear changes were noted in 12 patientes $(24 \%)$ on both sides of the tongue. These authors suggested that cytopathology can be used as a diagnosis method for the subclinical phase of $\mathrm{OHL}^{7}$.

Accurate diagnosis of OHL is important because it may serve as an early indicator of an undiagnosed HIV infection. Moreover, it may be of prognostic value ${ }^{4}$. However, according to many authors, OHL has rarely been described in the $\mathrm{HIV}^{+}$ pediatric population, with a prevalence varying from 0 to $6 \%{ }^{1,2,4,5,9,10,12,13,15,16,18,19,21}$.

The aim of this study was to verify OHL prevalence in HIV children using cytopathology.

\section{MATERIALS AND METHODS}

The procedures in this study were conducted in accord with the ethical standards established by the institution where the experiments were performed.

A hundred and twenty HIV pediatric patients aged less than 13 years were enrolled in this study. Patient data were collected by a confidential questionnaire previously authorized by the child's parents or legal guardian. Data such as age, route of HIV transmission, signs and symptoms, oral diseases, viral load, CD4 count, CD8 count and type of antiretroviral therapy were collected. Viral load was stratified in two groups: high (greater than 4.0 $\log _{10}$ ) and low (lower than $4.0 \log _{10}$ ) according to Grando et al. ${ }^{13}$ (2002) study.

Oral examinations were performed in all 120 patients under artificial light. The patients were evaluated for oral lesions and the dental aspects were not considered. Cytopathology specimens were obtained from the lateral borders of the tongue using an endocervicex brush (vagispec ${ }^{\circledR}$, Jaraguá do Sul, SC, Brazil), independently of the presence of lesion in that area. The material was carried over to an identifed glass slide, through rotatory movements of the brush. These glass slides were fixed in $90^{\circ}$ alcohol and packed in an appropriate plastic container. They were subsequently processed with Papanicolaou staining.

The laboratorial phase was performed at the Service of Pathological Anatomy, Antônio Pedro University Hospital, Fluminense Federal University (UFF), Niterói, RJ, Brazil. The slides were examined by two independent observers using a Nikon optical microscope (Labophot - 2, Tokyo, Japan).

Descriptive statistics, and the chi-square and Wilcoxon-Mann-Whitney tests were carried out using the SPSS program (version 10, Chicago, USA).

\section{RESULTS}

One hundred and twenty patients were enrolled: 69 (57.5\%) females and 51 (42.5\%) males with a mean age of $6.9 \pm 2.5$ years. All patients were infected by vertical transmission.

In 2 instances the medical record could not be located. Of the remaining 118 patients, 110 $(93.2 \%)$ were receiving antiretroviral therapy. Of these, $74(67.2 \%)$ were receiving highly active antiretroviral therapy (HAART).

The criteria for cytophatologic OHL diagnosis were the EBV-related characteristic alterations. Clinical OHL was identified in 2 cases (1.67\%). In both, the three EBV induced nuclear alterations were observed: Cowdry type A inclusions (Figure 1), ground-glass nuclei (Figure 2) and nuclear beading (Figure 3). Twenty subclinical OHL cases (16.7\%) were found. The total prevalence (clinical and subclinical) was $18.3 \%$ (22 cases). 


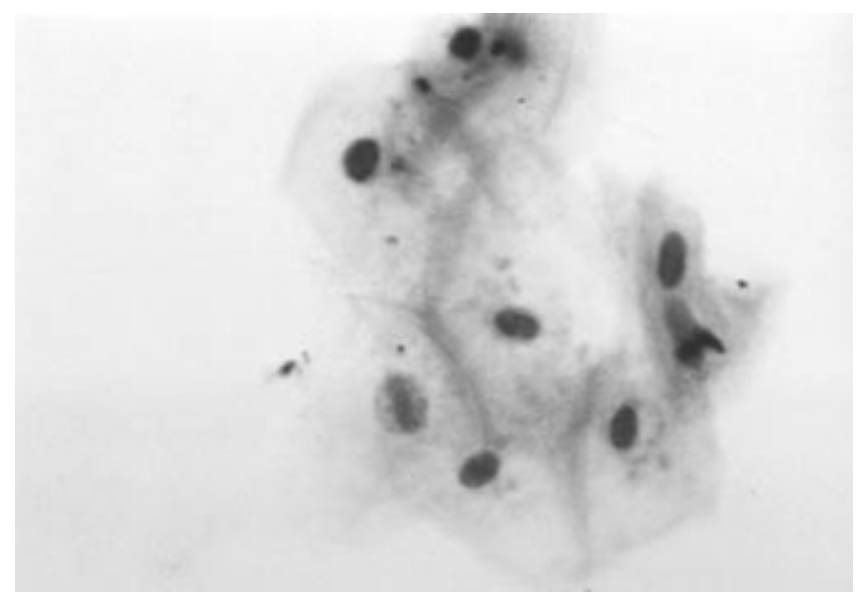

FIGURE 1 - Cowdry type A: eosinophilic inclusion surrounded by a clear zone or "halo". Papanicolaou stain, $100 \mathrm{X}$.

FIGURE 3 - Nuclear beading: peripheral margination and clumping of chromatin. Papanicolaou stain, $100 \mathrm{X}$.

\section{DISCUSSION}

In the first reported cases of OHL, the diagnosis was based on the clinical appearence of the lesion associated with no response to antifungical treatment, thus ruling out oral candidiasis $(\mathrm{OC})^{8,13}$. Nevertheless, several oral lesions may resemble OHL, including frictional kyperkeratosis, lichen planus, hyperplastic candidiasis, white sponge nevus and severe leukoedema ${ }^{14}$. OHL diagnosis is now based on cell morphology (histopathology and cytopathology), associated or not with EBV demonstration (immunohistochemistry, in situ hybridization, polymerase chain reaction or electronic microscopy). Many studies have demonstrated cytopathology specificity ${ }^{6,7,11}$. In HIV children, the accomplishment of a biopsy represents difficulty

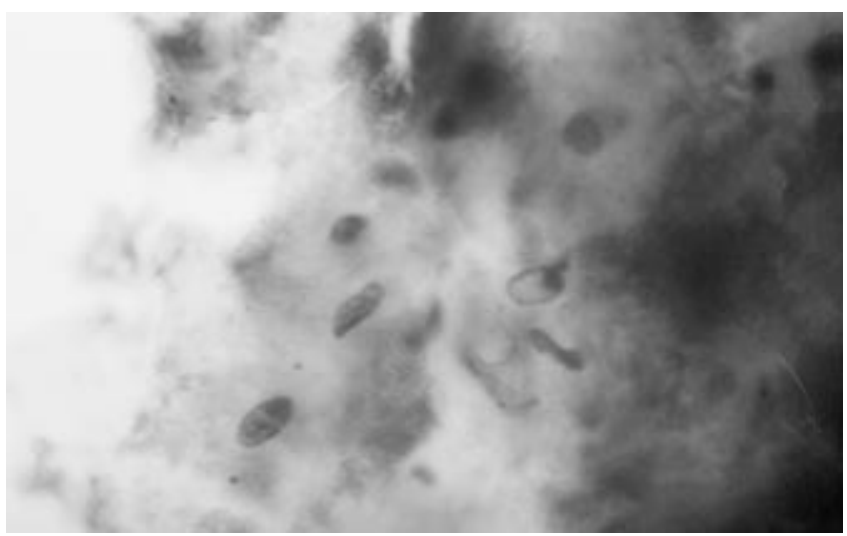

FIGURE 2 - Ground-glass nuclei: eosinophilic or basophilic inclusions that cause homogenization of the nuclear surface and peripheral margination of the chromatin. Papanicolaou stain, $100 \mathrm{X}$.

comparable to that involved in its accomplishment in adults, amplified by the delicate approach involved. Moreover, the cytopathology allows the diagnosis of subclinical OHL. In these cases, there is no visible clinical lesion, therefore not leading to a biopsy indication and compromising the diagnosis of subclinical OHL. Methods of identification of the EBV, because of its high cost, must be reserved for the doubtful cases, where the nuclear alterations are not characteristic of the disease or are absent.

Oral hairy leukoplakia is most often found on the lateral borders of the tongue. Some case reports describe lesions in other areas of the oral mucosa, such as buccal mucosa, lip mucosa, floor of the mouth, soft palate and pharyn $x^{23}$. We opted to collect material from the lateral borders of the tongue because it is the most common site of involvement.

Clinical OHL was observed in two instances $(1.67 \%)$. OHL prevalence in this study matches the prevalence described in the literature (0 a 6.7\%). However, in most of these studies, OHL diagnosis was based only on the clinical aspects.

OHL is an EBV disease whose primary infection occurs between 7 and 11 years of age. Chigurupati et $a .^{3}$ and Del Toro et al. ${ }^{5}$, in 1996, have stated that EBV exposure does not occur in younger children, thus justifying the low prevalence of $\mathrm{OHL}^{3,5}$. However, in our two clinical cases the patients had less than 7 years of age ( 4 and 5 years).

There are many hypotheses explaining the observed low prevalence of clinical OHL in HIVinfected children. One is the occurrence of Candida overlaying the OHL lesion, which is then commonly 
Dias EP, Israel MS, Silva Junior A, Maciel VA, Gagliardi JP, Oliveira RH. Prevalence of oral hairy leukoplakia in 120 pediatric patients infected with HIV-1. Braz Oral Res 2006;20(2):103-7.

mistaken for oral candidiasis (OC). In our two cases of clinical OHL there was OC overlaying the OHL lesion. OHL overlaid with OC is frequently reported in the literature, occurring in 50 to $75 \%$ of the reported cases. The authors believe that the epithelial penetration of hyphae of Candida $s p$. may allow contact between the EBV contained in the saliva and the cells of the epithelial prickly layer, where a higher concentration of EBV receptors can be found. Despite the frequent occurrence of Candida sp. in OHL lesions, either in scraped, cultured or histopathology specimens, Epstein et al. ${ }^{8}$ (1995) do not believe that OC is of etiologic importance because OHL does not resolve with aggressive antifungical therapy. Other hypotheses that have also been raised in the attempt to explain the low prevalence of OHL in children are: OHL may appear only transiently, secondary to intermittent changes in CD4 cell numbers ${ }^{9}$; children are not exposed to the innumerable strains of EBV that are necessary to produce the lesion ${ }^{9,19}$; OHL would be a more delayed symptom of HIV infection appearing in older children ${ }^{4,23}$.

The clinical significance and the prognostic implications of OHL in HIV-infected children are not yet well studied ${ }^{13}$. Many papers show the relationship between AIDS oral manifestations and CD4 cell counts and viral load in adults $2,3,6,16,23$. Some few authors believe that these same correlations do not exist among children ${ }^{9,12}$. The association between these AIDS markers and the presence of oral lesions in children is still not clear in the literature ${ }^{5,10,16}$.

Since the number of cases of clinical OHL is low, it is difficult to make a significant correspondence with the laboratory data. Fonseca et al. ${ }^{10}$ (2000) observed that children who presented

\section{REFERENCES}

1. Boer FAC, Percinoto C. Manifestações orais observadas em crianças com sorologia positiva para HIV. In: $16^{\mathrm{a}}$ Reunião da SBPqO: 1999; São Paulo. Painel. a214.

2. Bosco VL, Birman EG. Manifestações bucais em crianças com AIDS e em controles. Pesqui Odontol Bras 2002;16(1):711.

3. Chigurupati R, Raghavan SS, Studen-Pavlovich DA. Pediatric HIV infection and its oral manifestations: a review. Pediatr Dent 1996;18(2):106-13.

4. Costa LR, Villena RS, Sucasas PS, Birman EG. Oral findings in pediatric Aids: a case control study in Brazilian children. J Dent Child 1998;87(3):186-90.

5. Del Toro A, Berkowitz R, Meyerowitz C, Frenkel LM. Oral findings in asymptomatic (P-1) and symptomatic (P-2) HIVinfected children. Pediatr Dent 1996;18(2):114-6. a $\mathrm{T} 4 / \mathrm{T} 8$ ratio $<0.5$ were more susceptible to the development of oral lesions, as in our two cases of clinical OHL.

The total prevalence of OHL (subclinical and clinical) was $18 \%$ (22 cases). By reviewing the literature, we did not find any case report of subclinical OHL in HIV+ pediatric patients. This is the first study reporting subclinical OHL in HIV children.

Since the introduction of HAART therapy, a decline in oral manifestations has been observed. The use of HAART did not influence the occurrence of lesions among our patients.

The use of cytopathology has not been described for OHL diagnosis among children. This method is simple, efficient, low-cost, painless and not invasive. We suggest cytopathology as a standard procedure for diagnosing OHL in HIV-infected patients.

\section{CONCLUSIONS}

1. Prevalence of OHL in our HIV pediatric population (18\%) was larger than that reported in the literature.

2. Our study did not demonstrate a relationship between prevalence of OHL and severe immunodepression, viral load or HAART therapy.

\section{ACKNOWLEDGMENTS}

This study was supported in part by the Coordination for the Improvement of Higher Education Personnel (CAPES), Brasília, DF, Brazil. The authors wish to thank the John E. Fogarty International Center, through the AIDS International Training Research Program (AITRP), for its support.

6. Dias EP, Feijó EC, Polignamo GAC. Diagnóstico Clínico e Cito-histopatológico das Manifestações Bucais na AIDS. J Bras Doenças Sex Transm 1998;10(1):10-6.

7. Dias EP, Spyrides KS, Silva Junior A, Rocha ML, Fonseca EC. Leucoplasia pilosa oral: aspectos histopatológicos da fase subclínica. Pesqui Odontol Bras 2001;15(2):104-11.

8. Epstein JB, Fatahzadeh M, Matisic J, Anderson G. Exfoliative cytology and electron microscopy in the diagnosis of hairy leukoplakia. Oral Surg Oral Med Oral Pathol Oral Radiol Endod 1995;79(5):564-9.

9. Ferguson FS, Archard H, Nuovo GJ, Nachman S. Hairy leukoplakia in a child with AIDS - a rare symptom: case report. Pediatr Dent 1993;15(4):280-1.

10. Fonseca R, Cardoso AS, Pomarico I. Frequency of oral manifestations in children infected with human immunodeficiency virus. Quintessence Int 2000;31(6):419-22. 
Dias EP, Israel MS, Silva Junior A, Maciel VA, Gagliardi JP, Oliveira RH. Prevalence of oral hairy leukoplakia in 120 pediatric patients infected with HIV-1. Braz Oral Res 2006;20(2):103-7.

11. Fraga-Fernandez J, Vicandi-Plaza B. Diagnosis of Hairy Leukoplakia by Exfoliative Cytologic Methods. Am J Clin Pathol 1992;97:(2)262-6.

12. Gaitan-Cepeda L, Cashat-Cruz M, Morales-Aguirre JJ, Sanchez-Vargas L, Aquino-Garcia S, Fragoso-Rios R et al. Prevalence of Oral Lesions in Mexican Children with Perinatally Acquired HIV: Association with Immunologic Status. AIDS Patient Care STDS 2002;16(5):151-6.

13. Grando LJ, YurgeL LS, Machado DC, Silva CL, Menezes M, Picolli C. Manifestações estomatológicas, contagem de linfócitos T-CD4+ e carga viral de crianças brasileiras e norte-americanas infectadas pelo HIV. Pesqui Odontol Bras 2002;16(1).

14. Greenspan D, Greenspan JS, Conant M, Petersen V, Silverman S Jr, de Souza Y et al. Oral "hairy" leukoplakia in male homosexuals: evidence of association with both papilomavirus and a herpes-group virus. Lancet 1984;2:8314.

15. Greenspan JS, Mastrucci MT, Leggott PJ, Freese UK, De Souza YG, Scott GB et al. Hairy leukoplakia in a child (letter). AIDS 1988;2(2):143.

16. Howell RB, Jandinski JJ, Palumbo P, Shey Z, Houpt MI. Oral soft tissue manifestations and CD4 lymphocyte counts in HIV-infected children. Pediatr Dent 1996;18(2):11720.
17. Israel MS, Correia RP, Maciel VA, Dias EP. Manifestações orais associadas à infecção pelo HIV em crianças. Rev Bras Odontol 2002;59(5):335-7.

18. Itin PH, Bircher AJ, Litzisdorf Y, Rudin C. Oral hairy leukoplakia in a child: confirmation of the clinical diagnosis by ultrastructural examination of exfoliative cytologic specimens. Dermatology 1994;189(2):167-9.

19. Katz MH, Mastrucci MT, Leggott PJ, Westenhouse J, Greenspan JS, Scott GB. Prognostic Significance of Oral Lesions in Children With Perinatally Acquired Human Immunodeficiency Virus Infection. Am J Dis Child 1993;147(1):45-8.

20. Mabruk MJ, Flint SR, Toner M, Leonard N, Sheils O, Coleman DC et al. Detection of Epstein-Barr virus DNA in tongue tissues from AIDS autopsies without clinical evidence of oral hairy leukoplakia. J Oral Pathol Med 1995;24(3):109-12.

21. Magalhaes MG, Bueno DF, Serra E, Goncalves R. Oral manifestations in Brazilian HIV positive children. J Clin Pediatr Dent 2001;25(2):103-6.

22. Migliorati CA, Jones AC, Baughman PA. Use of exfoliative cytology in the diagnosis of oral hairy leukoplakia. Oral Surg Oral Med Oral Pathol 1993;76(6):704-10.

23. Ramos-Gomez F. Dental considerations for the paediatric AIDS/HIV patient. Oral Dis 2002;8 (Suppl II):49-54. 